\title{
Processing of Aluminium Alloys with High Content of Iron by Methods of Powder Metallurgy
}

Vojtěch Kučera, Filip Průša, Dalibor Vojtěch

Department of Metals and Corrosion Engineering, University of chemistry and technology Prague, Technická 5, 16628 Prague 6, Czech Republic. E-mail: kucerao@vscht.cz

Powder metallurgy could be an alternative way to ordinary casting technologies in the processing of aluminium alloys with high content of iron. Far more attention is given especially to technologies capable to produce ultrafine microstructures leading to desired mechanical properties. Binary alloy of aluminium and iron (AlFe $17 \mathrm{wt}$. \%) was prepared by mechanical alloying, centrifugal atomization and mechanical working followed by consolidation via spark plasma sintering and hot extrusion. Phase composition of the compact samples consisted of solid solution of iron in aluminium and of intermetallic phase identified as $\mathrm{Al}_{13} \mathrm{Fe}_{4}$. Very fine microstructure was achieved by combination of mechanical alloying and subsequent consolidation via spark plasma sintering and by combination of centrifugal atomization and hot extrusion. Compressive strength of these samples was 508 MPa and 637 MPa, respectively. Moreover, the AlFe17 alloy prepared by combination of centrifugal atomization and hot extrusion exhibited extraordinary ductility reaching almost $36 \%$.

Keywords: mechanical alloying, centrifugal atomization, spark plasma sintering, hot extrusion.

\section{Acknowledgement}

The authors wish to thank the Czech Science Foundation (project no. P108/12/G043) for its financial support of this research.

\section{References}

[1] C. SCHMITZ, J. DOMAGALA, P. HAAG, (2007). Handbook of Aluminium Recycling, Vulkan-Verlag GmbH.

[2] T.T. SASAKI, T. OHKUBO, K. HONO, (2009). Microstructure and mechanical properties of bulk nanocrystalline Al-Fe alloy processed by mechanical alloying and spark plasma sintering, Acta Materialia, 57 3529-3538.

[3] V.V. STOLYAROV, R. LAPOVOK, I.G. BRODOVA, P.F. THOMSON, (2003). Ultrafine-grained Al-5 wt.\% Fe alloy processed by ECAP with backpressure, Materials Science and Engineering: A, 357 159-167.

[4] N.A. BELOV, A.A. AKSENOV, D.G. ESKIN, (2002). Iron in Aluminium Alloys: Impurity and Alloying Element, Taylor \& Francis.

[5] A.F. ARMAS, J.A. TAYLOR, (2012). 11th International Congress on Metallurgy \& Materials SAM/CONAMET 2011Iron-Containing Intermetallic Phases in Al-Si Based Casting Alloys, Procedia Materials Science, 1 19-33.

[6] F. PRŮŠA, D. VOJTECH, A. BERNATIKOVÁ, D. DVORSKÝ, (2015). Mechanical alloying: A way how to improve properties of aluminium alloys, Manufacturing Technology, 15 1036-1043.

[7] F. PRŮŠA, D. VOJTĚCH, (2014). Properties of Al-based alloys prepared by centrifugal atomisation and hot extrusion, in: METAL 2014 - 23rd International Conference on Metallurgy and Materials, Conference Proceedings, pp. 1345-1350.

[8] F. PRŮŠA, D. VOJTĚCH, M. BLÁHOVÁ, A. MICHALCOVÁ, T.F. KUBATÍK, J. ČÍŽEK, (2015). Structure and mechanical properties of $\mathrm{Al}-\mathrm{Si}-\mathrm{Fe}$ alloys prepared by short-term mechanical alloying and spark plasma sintering, Materials \& Design, 75 65-75.

[9] V. KUČERA, F. PRŮŠA, D. VOJTĚCH, (2016). Processing of Al-Fe scraps by powder metallurgy, Manufacturing Technology, 16726 - 732.

[10] Y. MINAMINO, Y. KOIZUMI, N. TSUJI, N. HIROHATA, Y. OHKANDA, (2004). Microstructures and mechanical properties of bulk nanocrystalline $\mathrm{Fe}-\mathrm{Al}-\mathrm{C}$ alloys made by mechanically alloying with subsequent spark plasma sintering, Science and Technology of Advanced Materials, 5 133-143.

[11] M. KRASNOWSKI, T. KULIK, (2009). Nanocrystalline and amorphous Al-Fe alloys containing 60-85\% of Al synthesised by mechanical alloying and phase transformations induced by heating of milling products, Materials Chemistry and Physics, 116 631-637.

[12] C. SURYANARAYANA, (2001). Mechanical alloying and milling, Progress in Materials Science, 46 1-184. 
[13] M. SUÁREZ, A. FERNÁNDEZ, J.L. MENÉNDEZ, R. TORRECILlAS, H.U. KESSEL, J. HENNICKE, R. KIRCHNER, T. KESSEL, (2013). Challenges and Opportunities for Spark Plasma Sintering: A Key Technology for a New Generation of Materials, InTech.

[14] P.C. ANGELO, R. SUBRAMANIAN, (2008) Powder Metallurgy: Science, Technology and Applications, PHI Learning.

[15] S.S. NAYAK, M. WOLLGARTEN, J. BANHART, S.K. PABI, B.S. MURTY, (2010). Nanocomposites and an extremely hard nanocrystalline intermetallic of Al-Fe alloys prepared by mechanical alloying, Materials Science and Engineering: A, 527 2370-2378.

[16] R. HONZÁTKO, Š. MICHNA, J. CAIS, (2013). The influence of porosity on mechanical properties of casts produced from Al - Si Alloys, Manufacturing Technology, 13 319-324.

Paper number: M2016180

Copyright $\odot$ 2016. Published by Manufacturing Technology. All rights reserved. 